\title{
Educational differentials in fertility intentions and outcomes: family formation in Flanders in the early 1990s
}

\author{
David De Wachter and Karel Neels*
}

\begin{abstract}
Over the last decades the majority of European countries have witnessed fertility levels considerably below replacement. Particularly completed cohort fertility below two children per woman has raised concerns whether this trend corresponds to a decline of fertility intentions or represents a discrepancy between intended and realised fertility. Using data from the Fertility and Family Survey (FFS) conducted in 1991, we look at fertility intentions of women aged 20-39 in Flanders, documenting how intentions differ in terms of education of women and their partners, activity status and household position. For a larger group of women, we subsequently compare the effects of these characteristics on first-, second- and third-birth hazards in a prospective study based on longitudinal microdata from the 1991 and 2001 Belgian censuses. Our results indicate that lifetime fertility intentions in 1991 were above the replacement level, but also that the proportion of women having a child in the three-year period following the 1991 census is lower than the short-term intentions suggested in the FFS, particularly for first births. We find evidence of a positive educational gradient in both fertility intentions and birth hazards. For the highly educated, higher birth hazards are associated with a stronger attachment to the labour market (both before and after parenthood), homogamy to highly educated partners and more frequent uptake of (in)formal child care.
\end{abstract}

\section{Introduction}

Over the last decades the majority of European countries have witnessed fertility levels substantially below replacement, irrespective of whether period or cohort fertility indicators are considered (Frejka and Sobotka 2008). Despite recent

\footnotetext{
* David De Wachter (corresponding author), Interface Demography, Vrije Universiteit Brussel, Belgium. Email: David.De.Wachter@vub.ac.be

Karel Neels, Sociology Department, University of Antwerp, Belgium. Email: Karel.Neels@ua.ac.be
} 
increases in the period total fertility rate, most countries in Europe continue to record period fertility below two children per woman. Whereas low period fertility can be a result of tempo effects and therefore uninformative about the family size of the cohorts considered (Bongaarts and Feeney 1998; Sobotka and Lutz 2009), completed cohort fertility below replacement raises questions on whether these levels reflect declining fertility intentions or an increasing discrepancy between fertility intentions and outcomes. Particularly the theory of the Second Demographic Transition has suggested that low fertility may correspond to an actual decline of fertility intentions, in line with changing value orientations that emerged since the 1960s (Lesthaeghe and van de Kaa 1986). Although fertility intentions have been shown to decline over time - and have fallen below replacement level in a limited number of countries (Sobotka 2009) most European countries report fertility intentions that lie around or above this level (Van Peer 2002; Goldstein et al. 2003; Testa 2007). As a result, cohort fertility below replacement may reflect an "unmet need" for children (Philipov et al. 2009). In this respect, micro-economic theories have drawn attention to the changing opportunity costs of childbearing and the role incompatibility between parenthood and female labour force participation (Becker 1981). Macro-economic explanations have interpreted the fertility gap in terms of structural changes in the economic context and labour markets, such as economic recession, rising unemployment levels and difficulties in finding stable employment (Sobotka et al. 2011). Finally, theories that stress the role of ideational factors have argued that changes in value orientations may have affected fertility indirectly because changing family patterns (e.g. rising divorce rates) and the increasing popularity of more unstable living arrangements (e.g. unmarried cohabitation and LAT relationships) have lead to a situation where a growing number of men and women do not achieve their desired fertility levels (Lesthaeghe and Willems 1999).

Most of the aforementioned interpretations have attributed a key role to education. In the literature on postponement and subreplacement fertility, rising education has been associated with the dissemination of postmaterialist values and the emergence of low family size preferences (Lesthaeghe and Surkyn 1988), the rise of alternative living arrangements (Lesthaeghe and van de Kaa 1986), but also with rising opportunity costs of childbearing (Becker 1981). Increasing enrolment in education has further been identified as one of the pathways through which unemployment and economic uncertainties affect fertility (Kreyenfeld 2010). To the extent that increasing enrolment and educational attainment are accompanied by intended family sizes around the replacement level, a recovery of period fertility may be expected, provided that societal conditions reduce the incompatibility between female employment and parenthood. If on the other hand future increases of educational attainment entail further declines in intended family size, a recovery of period fertility is much less likely to occur and further declines may result (Sobotka 2009). 
In this article we study fertility intentions and fertility outcomes in Flanders (Belgium) during the early 1990s. This period was characterised by one of the lowest levels of period fertility observed since the baby bust in the early 1970s (period TFR of 1.58 in 1991), adverse economic conditions (e.g. a GDP decline of 1.3 per cent in 1993) and rapidly increasing unemployment (female unemployment levels increasing from 12.8 per cent in 1990 to 17.0 per cent in 1994) (OECD 2011). Using data from the Fertility and Family Survey (FFS), we first look into the patterning of lifetime fertility intentions (number of children wanted) and short-term fertility intentions (intention of having children within the next three years) by education, activity status and household position of women aged 20-39 in 1991. These cohorts accelerated the postponement of parenthood relative to earlier cohorts (Neels 2006), while at the same time having fertility ideals and desires that exceeded the replacement level (Van Peer 2008). The analysis of fertility intentions provides the background for the prospective analysis of longitudinal census data aimed at identifying factors that stimulate or delay entry into parenthood and progression to second and third births in the 3-year period following the 1991 census. We focus specifically on educational differentials in intentions and outcomes and the way education is related to household positions and the activity status of both women and their partners. Because there is no record linkage between the FFS and the Belgian census at the individual level, our study can only draw conclusions as to the aggregate consistency between fertility intentions and fertility outcomes. The findings suggest that fertility intentions and outcomes are higher among women with higher levels of education, and that higher birth hazards are associated with sustained labour force participation of women and their partners before and after entry into parenthood, as well as frequent uptake of informal and particularly formal child care. ${ }^{1}$ This finding is consistent with the strong decrease of childlessness among highly educated women found in cohorts born between 1930 and 1960 and the more frequent progression to second and third births (Gadeyne et al. forthcoming).

The article is structured as follows. Section 2 discusses the theoretical framework. Section 3 provides information on the research design, the data from the Fertility and Family Survey of 1991 and the data from the 1991 and 2001 censuses. The results are discussed in Section 4. Section 5 concludes with a discussion of the main findings.

The results discussed in this study document educational differentials in fertility intentions and fertility outcomes in Flanders in the early 1990s. More recent results based on the Survey on Income and Living Conditions (EU-SILC) and the Generations and Gender Survey (GGS) indicate, however, that similar educational differentials in the combination of paid work and family formation as well as differential uptake of (in)formal child care are still found in 2009. 


\section{Theoretical framework}

Since the 1970s most European countries have witnessed a strong expansion of the educational system with increasing female enrolment in tertiary education (World Bank 2011). Several studies have documented that educational enrolment and the pursuit of tertiary education substantially delay entry into parenthood (e.g. Hoem 1986; Blossfeld and Huinink 1991). Some researchers have suggested that the prolongation of educational careers is likely to result in lower completed fertility because women have less time to achieve their intended family size (Berrington 2004). Although higher education has frequently been associated with lower completed fertility (van de Kaa 2001), a considerable number of studies with the exception of a number of references (e.g. Van Peer 2002; Sobotka 2009) - show positive effects of educational attainment on fertility intentions. Mills et al. (2008) find higher fertility intentions among highly educated women, as well as highly educated partners, for Italy in 2003 and the Netherlands in 2004-05. Using western German panel data for 1988 and 1994-95 Heiland et al. (2005) find that highly educated individuals are more likely to prefer families with three or more children over families with two children. Based on Eurobarometer data for 2001 the authors further suggest that the positive relationship between educational attainment and reproductive preferences seems to hold in a broader western European context. Similar conclusions are drawn by Liefbroer (2009) who finds that highly educated women report higher family size intentions at the start of their family formation than less educated women, as shown in a six-wave panel study for the Netherlands conducted between 1987 and 2005-06. Philipov et al. (2006) report that highly educated women in Hungary in 2001 more frequently intend to have a second child in the next two years compared to less educated women. Also van de Kaa (2001) finds support for a positive relationship between education and the number of children ultimately expected by young women based on Fertility and Family Survey data for the early 1990s.

Previous research on fertility intentions in Flanders is in line with the positive educational gradient found in other countries. Drawing from the Fertility and Family Survey data for 1991 Van Peer (2008) finds that the ideal and desired number of children is higher among highly educated women in Flanders. At the same time she finds that women in full-time and part-time employment report a significantly lower number of desired children than unemployed women. For men the reverse conclusion is drawn: employed men desire a significantly higher number of children than unemployed men. The latter finding suggests that employed women, unlike men, experience or anticipate difficulties in combining parenthood with a professional career and consequently adjust their fertility intentions downward (Liefbroer 2009). 


\subsection{Work trajectories and opportunity costs}

Micro-economic theories have extensively considered the interplay between education, labour force participation and fertility. According to Becker, two mechanisms link education to fertility (Becker 1981; Liefbroer et al. 1999). The income effect implies that the highly educated generally have higher earnings, putting them in a better position to support a family and suggesting a positive effect of education on fertility. The price effect, on the other hand, implies that family formation entails opportunity costs as less time can be spent on wage labour. Assuming a gendered division of tasks within households, the income effect is assumed to be preponderant for men as they specialise in wage labour and family formation is unlikely to interfere with their role as income provider. For women, the price effect is expected to dominate as the combination of childrearing and (particularly full-time) work is likely to raise compatibility issues. Rising female educational attainment has increased the earning potential of women, leading in turn to their higher participation in the labour force. As the cost of time spent on nonmarket activities increases, the relative cost of children increases as well, thus reducing the demand for children (Becker 1981). Even if opportunity costs were reduced, Becker and Lewis (1973) argue, however, that the increase in household income resulting from female employment does not necessarily entail higher completed fertility as there will also be a trade-off between the quality of children and the quantity of children.

The presumed incompatibility between female labour force participation and family formation is likely to depend on the part of the life-course considered. Liefbroer and Corijn (1999) suggest that highly educated people are more likely to enter long-term career tracks where the increase in earnings is gradual, because age and experience are important determinants of wages. This combination of factors makes it unlikely that highly educated women will have children early in their careers, as this would presumably hamper their prospects of entering career tracks typical for people with higher education (Liefbroer and Corijn 1999). Hence, highly educated women are assumed to postpone childbearing up to a point where they consider themselves to be sufficiently established in a career track and where taking a temporary break from the labour market is also considered less damaging for future career development (Kreyenfeld 2010).

Because job opportunities are largely determined by economic context, particularly for younger people entering the labour market, the delay of fertility can be expected to increase in periods of adverse economic conditions. Several studies have addressed the effects of economic context and economic insecurities on fertility at the aggregate level by relating trends in unemployment to indicators of period fertility. Most results point in the direction of a pro-cyclical effect, suggesting that individuals postpone childbearing decisions in times of high unemployment (Neels 2010; Sobotka et al. 2011). Gustafsson (2001) showed that the postponement of parenthood in Europe has increased substantially since the 
1970s and comparing trends of the 1990s to the 1980s, has been increasing even further. During this period many European countries experienced significant rises in unemployment levels, which - together with increasing enrolment rates in tertiary education - have seriously affected the postponement of childbearing (Sobotka et al. 2011). Fewer studies have tackled the effect of unemployment at the individual level, and the results point in different directions (Kravdal 2002; Engelhardt and Prskawetz 2004; Kreyenfeld 2010). On the one hand, unemployment can be considered a 'cheap' time for childbearing as opportunity costs are reduced compared to periods of employment, resulting in an acceleration of fertility. On the other hand, unemployment in most cases entails a position of greater financial insecurity, resulting in a negative effect on fertility. Unemployment could then result in postponement of childbearing until stable employment is found because having a child may be considered to hamper (re)entry into the labour force (Meron and Widmer 2002). As a result, the effect of unemployment on fertility is likely to vary in terms of educational attainment. Since highly educated women are more career-oriented and generally have better employment prospects, unemployment is likely to provide a strong incentive to postpone fertility until stable employment has been secured (Kreyenfeld 2006, 2010). For less educated women, unemployment may have a less negative or even positive effect on fertility. Research further suggests that women with limited employment opportunities may tend to reduce uncertainty in life by choosing motherhood as an alternative career (Friedman et al. 1994; Vikat 2004). Several studies have documented the interaction between educational attainment and economic insecurity. Kreyenfeld (2010) shows that highly educated women in western Germany are more likely to postpone childbearing when confronted with employment uncertainties, while less educated women often respond to this situation by making the transition into motherhood (see Vikat 2004 for Finland). Also in Belgium, the negative effect of recession and unemployment on entry into parenthood was found to be more articulated among highly educated women (Neels 2010; Neels and De Wachter 2010).

The economic reading of the fertility decline has been criticised for not contextualising the work-fertility relationship within the institutional context. Over the last decades a growing number of European countries have increasingly implemented family and social policies to alleviate the incompatibility between motherhood and female employment (Brewster and Rindfuss 2000; Gauthier 2007). In the countries considered, the increasing availability of formal child care and parental leave systems have substantially reduced the opportunity costs associated with parenthood. The availability of formal child care gives women the opportunity to remain attached to the labour market without having to forgo parenthood. Entry into parenthood is less likely to entail a long-term or permanent retreat from the labour market as a result. To the extent that mothers manage to combine parenthood and labour force participation, and think they will be able to do so in light of continued family formation, the perceived opportunity costs of an 
additional child are also likely to be lower. In this scenario, the income effects may increasingly outweigh opportunity costs, resulting in a positive effect of female employment on fertility (Neels 2011). Evidence suggests, however, that the uptake of family policy benefits is not neutral in terms of socio-economic background (Neyer and Andersson 2008). In Flanders, highly educated mothers more frequently take up parental leave and more often make use of formal child care (Desmet et al. 2007; Ghysels and Van Lancker 2009). This implies that highly educated women are less likely to permanently or completely retreat from the labour market on the one hand and are also in a better position to have a second or third child.

Apart from parental leave and (in)formal child care, part-time employment may constitute an alternative strategy to reconcile parenthood with female labour force participation (Hakim 2003). Wright and Hinde (1991) note, however, that there are qualitative differences between full-time and part-time jobs besides the number of working hours. Part-time jobs offer lower earnings and/or fewer benefits than full-time jobs, but also little opportunity for upward professional mobility (see also Blossfeld and Hakim 1997). Similarly, Connolly and Gregory (2010) show for British women that part-time employment is two-faced. On the one hand it allows women to remain attached to the labour market until full-time work is resumed. On the other hand some women fall into a parttime/unemployment cycle with a detrimental impact on further career development. From the latter perspective part-time employment is a less advantageous labour market position and particularly highly educated women may be less likely to consider part-time employment as an attractive career path after entering parenthood. Among women with children, part-time work is thus likely to involve a selection of more child- and family-oriented women who are prepared to reduce their labour force participation for family formation.

Finally, the effects of economic inactivity and unemployment on fertility should be considered within the household and institutional context. The effect of female unemployment on fertility outcomes is likely to vary depending on the partner's activity status. Most studies do not take partner activity status into account, although the situation where both partners are unemployed is quite different from the one where a woman (temporarily) retreats from the labour market while her partner remains employed. In the second case, the level and duration of unemployment benefits may further mediate the effect of unemployment on entry into parenthood and subsequent fertility decisions. Given that unemployment benefits in Belgium are unlimited in time (OECD 2007), benefits may provide an alternative income to employment, reducing the negative income effects associated with unemployment. Even in the light of such benefits, it seems unlikely that highly educated women would consider unemployment to be an attractive position. 


\subsection{Household positions and value orientations}

Whereas micro-economic theories have assumed tastes and fertility preferences to be stable, the theory of the Second Demographic Transition coined by Lesthaeghe and van de Kaa (1986) suggests that changes in nuptiality and fertility reflect a demand for larger individual autonomy, an increasing emphasis on symmetric gender roles, a constant re-evaluation of relationship quality, disengagement from long-term commitments such as marriage and parenthood and the spread of postmaterialist or "higher order" needs (Lesthaeghe and Neels 2002). These broad ideational changes have altered views about household and family formation and have in turn fostered an inclination toward smaller families (van de Kaa 2001) resulting in structural below-replacement fertility (Lesthaeghe and Meekers 1986). The dissemination of post-materialist value orientations to broader layers of the population is further associated with the increasing educational attainment of subsequent birth cohorts (Lesthaeghe and Surkyn 1988). Higher education is associated with more tolerant attitudes toward alternative living arrangements and non-marital childbearing. Studies relating value orientations to household positions have found that singles and unmarried cohabitants express more nonconformist attitudes regarding marriage and family compared to their married age-mates. The values-based selection of individuals who are less child- and family-oriented into alternative living arrangements (Surkyn and Lesthaeghe 2004; Liefbroer 2009) and the adaptation of value orientations following the transitions into specific household types lead to a clear differentiation of family size intentions in terms of household positions (Lesthaeghe 2002).

Overall, however, there is not much evidence that post-materialist value orientations and rising education have had a major negative impact on fertility intentions. Using data from the Fertility and Family Surveys, van de Kaa (2001) finds that neither the number of children ultimately wanted nor the number of children considered ideal show significant variation in terms of post-materialist value orientations. He does find, however, that women with post-materialist values start family formation later and realise lower completed fertility. The latter finding suggests that post-materialist value orientations and rising education affect fertility indirectly through the choice for alternative and less stable living arrangements. In this respect, Sobotka (2008: 208) notes, however, that "[w]hile fertility and marriage postponement, as well as voluntary childlessness, have been heralded by highly educated women, less educated individuals are often at the forefront of the rise of unstable living arrangements and non-marital fertility. Paradoxically, highly educated people, who have generally more positive attitudes towards the new family forms, resist longest the erosion of the 'bourgeois family', especially when they decide to have children." Previous research for Flanders corroborates this notion. Several studies report a strong connection between marriage and childbearing, particularly among highly 
educated women (Van Bavel and De Wachter 2007; Neels and De Wachter 2010).

Also the suggestion that rising divorce rates and the less stable character of non-marital living arrangements have contributed to the fertility gap has not remained uncontested. First, aggregate indicators suggest that the positive correlation between marriage and fertility has weakened and even reversed over the last decades. Countries characterised by lower total first marriage rates now have higher fertility levels. Similarly, the previously negative correlation between divorce rates, the proportion of extra-marital births and total fertility has turned positive (Billari and Kohler 2004). Second, also at the individual level there are indications that divorce and the more fragile character of non-marital unions do not necessarily result in lower completed fertility. Several studies suggest that men and women who choose to remarry or to cohabit after a previous relationship frequently (intend to) have a child with their new partner (e.g. Vikat et al. 1999; Thomson and Li 2002; Meggiolaro and Ongaro 2008).

\subsection{Hypotheses}

Based on the review of the literature, we draw up hypotheses separately for women $(\mathrm{H} 1-\mathrm{H} 3)$ and their male partners (H4). For women we additionally distinguish between lifetime intentions (H1), entry into parenthood (H2) and progression to second and third births (H3). Highly educated women are expected to have higher fertility intentions if they have good opportunities to combine their employment and family life. Considering parity and distinguishing between shortterm and lifetime intentions this leads to the following hypotheses:

H1 Lifetime intentions are higher among highly educated women given their favourable prospects in the labour market, homogamy with highly educated partners and a higher earning potential.

Compared to lifetime intentions, short-term intentions and actual fertility outcomes are likely to take current circumstances into account. Considering entry into parenthood, this gives rise to the following hypotheses:

H2A Unemployment and economic inactivity affect short-term intentions and fertility in a negative way. We expect this effect to be particularly articulated among highly educated women as they are inclined to postpone family formation until they have acquired a labour market position where a temporary break for family formation is considered less harmful.

H2B Living arrangements other than marriage are expected to have a negative effect on short-term intentions and fertility. This hypothesis rests on two premises: a) non-marital living arrangements are less stable than marriage, and b) women who are less family oriented are more likely to live in non-marital living arrangements. 
After entry into parenthood, the incompatibility between childrearing and employment can be resolved by a (partial) retreat from the labour market to take up care responsibilities or by making use of (in)formal child care. The strategy is likely to differ in terms of women's educational level and to have implications for the progression to second and third births. This leads to the following hypotheses:

H3A Highly educated women are less likely to retreat from the labour market after entry into parenthood. This hypothesis again rests on two premises: a) highly educated women are more likely to be work-oriented and b) the opportunity cost of economic inactivity for them is larger.

H3B The negative effect of unemployment and wage labour inactivity is weaker for the progression to second and third births. This hypothesis rests on the premise that family-oriented women are more likely to retreat from the labour market, resulting in self-selection into unemployment and economic inactivity.

H3C Living in unmarried cohabitation is linked to higher second and third births hazards for couples where at least one of the partners is divorced or separated. This hypothesis is based on the premise that couples who formed a new union after divorce or separation often try to cement their new union by having a baby.

Finally, for male partners we expect the labour market position to be largely invariant throughout family formation. As a result, the income effect is expected to prevail over the (opportunity) costs of childbearing. This leads to the final hypothesis:

H4 For male partners, higher education and employment have positive effects on both entry into parenthood and progression to second and higher-order births.

\section{Data and methods}

The analysis consists of two parts that draw data from different sources. The first part focuses on fertility intentions and uses cross-sectional data from the Fertility and Family Survey (FFS) conducted in 1991. The second part focuses on fertility outcomes and uses a prospective research design based on longitudinal microdata from the 1991 and 2001 Belgian censuses. Both datasets concern only Flanders. All analyses pertain to women who are no longer enrolled in education. Section 3.1 discusses the different indicators of fertility intentions drawn from the FFS. The prospective research design based on census data is discussed in Section 3.2. 


\subsection{Fertility and Family Survey}

The data on fertility intentions are drawn from the 'Nationale Enquête Gezinsontwikkeling' (NEGO V) which was conducted in Flanders and Brussels between March and October 1991 among 5433 respondents aged 20-40. The survey was subsequently included in the 'Fertility and Family Survey' programme of the Population Activity Unit of UNECE and is routinely referred to as the FFS (e.g. Callens 1995; Van Peer 2002). In this article we restrict the analysis to fertility intentions of 2847 female respondents aged 20-39 in Flanders.

Based on the FFS we construct two indicators of fertility intentions. The first indicator refers to the number of children women want at the time of the interview. We refer to this indicator as lifetime fertility intentions because no further reference is made to the timing of these births. Women could state the exact number of children wanted ( 88.3 per cent) or a range (10.4 per cent) and a small group refused or failed to answer the question (1.4 per cent). In cases where a range was specified, women were assigned the range's midpoint in the calculation of the average number of children wanted (e.g. a value of 2 children was assigned to women providing a range of 1 to 3 children). Additional sensitivity analyses were performed to gauge the effect of alternative handling of missing values as implicit assumptions regarding undecided respondents may substantially affect results regarding fertility intentions (Sobotka 2009). We compared the situation where missing values were discarded from the analyses to the situation where missing cases were attributed a value of 0 , assuming that undecided respondents may consider childlessness as the preferred (but unreported) outcome. Given the limited number of missing values, the different handling was found to have little impact on lifetime fertility intentions (an average of 2.08 children wanted when missing values were excluded from the analysis, compared to 2.04 when they were assigned a value of 0 ). Hence, the results reported in Section 4 refer to the more conventional treatment where missing values are excluded from the analysis.

The second indicator refers to the intention of having a child within the next three years. Among respondents who had not yet reached their desired number of children at the time of the survey, the FFS probes whether they intend to have a(nother) child in the next three years (current pregnancies excluded). Given the explicit reference to timing of births, we refer to this indicator as a measure of short-term fertility intentions. Among the 1470 women aged 20-39 who were asked this question, 117 refused or failed to provide an answer (4.1 per cent). Among the valid answers, 251 answered 'no' or 'rather no' (18.6 per cent), 145 women indicated being in doubt (10.7 per cent) whereas 957 women picked 'rather yes' or 'yes' (70.7 per cent). Because the intention of having a child in the next three years is subject to varying degrees of uncertainty, two variants are presented regarding short-term fertility intentions. In the low variant only the more decided women ('yes') are considered as having an intention to have 
a(nother) child, whereas the higher variant also includes women who are somewhat less determined regarding their intentions for the next three years (including 'rather yes' and 'yes'). Women who had reached or surpassed their intended family size were assumed not to have the intention of having another child in the next three years in both variants.

The analysis of short-term and lifetime fertility intentions uses following covariates: i) educational level of both women and their partners, distinguishing three levels: no education, primary and lower secondary education (low), higher secondary education (medium) and tertiary education (high), ii) women's activity status, distinguishing four categories: full-time employment, part-time employment, job seekers and women in economic inactivity (i.e. housekeepers, disabled persons and unemployed who were not seeking employment), iii) partner activity status, distinguishing two categories: employed partners (fulltime or part-time employment) versus partners who are not employed (partners who are economically inactive or seeking employment) and iv) household position, distinguishing women who live with their parents (with parents), singles, married women (married), women living in unmarried cohabitation (cohabiting) and a small group of women in other types of living arrangements (other).

Analysis of variance was used to test covariate effects on lifetime fertility intentions for significance: F-values and corresponding significance levels are included in footnote. Analyses on short-term fertility intentions are run separately by parity. Covariate effects on short-term intentions are tested for significance using binary logistic regression analysis: the values of the likelihood ratio tests and corresponding significance levels are equally included in footnote.

\subsection{Belgian census data}

The analysis of fertility outcomes uses longitudinal microdata drawn from the 1991 and 2001 censuses. We use a prospective research design where characteristics of women and their partners recorded in the census of 1 March 1991 are linked to individual fertility outcomes registered in the census of 1 October 2001. For women aged 14 and older, the 2001 census provides complete maternity histories up to the 12th live birth. Apart from the maternity histories, the 2001 census does not provide time-varying retrospective information on activity status, nor detailed time-varying information on changes in the relationship status. However, as women are likely to change occupational status and/or household positions over time, the covariates recorded in the 1991 census may become increasingly outdated during the 10-year interval between both censuses. As a result, the observation window was limited to the 3-year period between 1 January 1992 and 31 December 1994. In addition, the lag between the measurement of covariates on 1 March 1991 and entry into the risk set on 1 January 1992 reduces issues of state and rate dependence in hazard models, i.e. changes in activity status or household position in anticipation or as a 
result of childbearing (Singer and Willett 2003). The research population consists of women aged 20-39 in 1991 living in Flanders.

The analysis uses fixed-effects hazard models of first, second and third births occurring between 1992 and 1994. Because event occurrence is measured in years, we resort to discrete-time models using a complementary log-log link function (Allison 1982; Singer and Willett 2003). The antilog of the parameter estimates thus allows an interpretation in terms of hazard ratios. In all models, the time variable consists of three categories representing the subsequent years of the observation window, with 1992 being used as the reference category. Additional duration dimensions in the analysis of first-birth hazards are the duration in period difference since age 15 . The variable is included in the model as a time-varying covariate (quadratic effect). For second and third births additional duration dimensions are the duration in years since the first and second child, respectively (quadratic effect). For the analysis of second-birth hazards, age of women at the birth of their first child is included in the model as a time-constant variable (quadratic effect). Similarly, age of women at the birth of their second child is included in the model of third-birth hazards. All models are stratified by parity on 1 January 1991 (i.e. childless, 1 child and 2 children) and level of education. Three educational levels are distinguished: no education, primary and lower secondary education (low), higher secondary education (medium) and tertiary education (high). The stratification procedure is motivated by the fact that the effects of activity status and household position are assumed to vary in terms of educational level and parity.

For every educational stratum, two models are estimated. The first model only takes characteristics of women into account. The second model is restricted to women living with a partner on 1 March 1991 and additionally includes activity status and educational level of the partner as covariates in the model.

\section{Results}

Results on fertility intentions based on the FFS are presented in Section 4.1. These results provide the background for the results on fertility discussed in Section 4.2. Because there is no record linkage between the FFS and the Belgian census data at the individual level, we cannot analyse fertility outcomes conditional on the intention of having a(nother) child. The results therefore only document the consistency of intentions and outcomes at an aggregate level for the groups considered. Previous research has clearly documented the link between intentions and fertility outcomes at the individual level (Philipov et al. 2009; Schoen et al. 1999; Spéder et al. 2010). 


\subsection{Fertility intentions}

Although completed cohort fertility below replacement has raised questions on whether this level corresponds to low-fertility intentions of recent cohorts, results from the FFS suggest that low fertility does not reflect a decline of lifetime fertility intentions below the replacement level among women aged 20-39 at the time of the survey. Overall, the number of children wanted reaches the replacement level with an average of 2.08 children per woman (Figure 1). The breakdown by age indicates, however, that lifetime fertility intentions vary significantly over the age groups considered. ${ }^{2}$ Among women aged 25 and older, lifetime fertility intentions are consistently around 2.10 children per woman, whereas lifetime intentions have declined below the replacement level in the youngest age group, reaching an average of 1.94 children wanted among women aged 20-24 (birth cohorts 1966-70). Comparing lifetime intentions to realised fertility indicates that intentions materialise gradually over the life course, but even in the oldest age group the average number of children actually born is substantially lower than the number of children wanted. As the increase of cohort fertility after age 39 is generally small, the results of the FFS suggest a fertility gap for these cohorts with completed fertility falling short of lifetime fertility intentions. Given that the FFS provides a cross-sectional measurement of fertility intentions, it is unclear to what extent these older cohorts have already adjusted their lifetime intentions downward over time, as life course theories suggest (Liefbroer 2009). For the younger age groups, the low levels of realised fertility are consistent with the trend of fertility postponement in Belgium in the 1980s and 1990s, but the lifetime fertility intentions of 1.94 children per woman suggest substantial potential for recovery of period fertility levels compared to the levels recorded in the early 1990s (Bongaarts 2001; Sobotka 2009).

The breakdown of the number of children wanted in Table 1 indicates how lifetime intentions are influenced by educational level of women and their partners, activity status of women, partner employment and household position. Consistent with findings in the literature, increasing educational attainment of both women and their male partners is associated with significantly higher lifetime fertility intentions and this effect is similar across age groups. ${ }^{3}$ Lifetime fertility intentions also vary significantly in terms of the activity status of women. ${ }^{4}$ In the oldest age group, lifetime fertility intentions are substantially lower among women working full-time, whereas part-time employment and

\footnotetext{
The effect of age on lifetime fertility intentions is significant with $\mathrm{F}=5.19, \mathrm{p}<0.010$.

3 Educational level of women and their partners has a significant effect on lifetime fertility intentions with $\mathrm{F}=24.199(\mathrm{p}<0.001)$ and $\mathrm{F}=18.800(\mathrm{p}<0.001)$, respectively.

4 The effect of female activity status on lifetime intentions is not significant for women aged 20$24(\mathrm{~F}=1.474, \mathrm{p}>0.050)$. Significant effects of activity status are found for women aged 25-29 $(\mathrm{F}=7.387, \mathrm{p}<0.001)$, women aged $30-34(\mathrm{~F}=15.123, \mathrm{p}<0.001)$ and women aged $35-39$ $(\mathrm{F}=21.191, \mathrm{p}<0.001)$.
} 
economic inactivity are associated with higher fertility intentions. The effect of activity status is also significant among women aged 30-34 and women aged 25-29, but the negative effect of full-time employment is gradually diminishing among younger age groups. Economic inactivity is consistently associated with higher fertility intentions across age groups. Among women aged 20-24 activity status does not have a significant impact on intended number of children. In contrast to the women's activity status, that of their partners has no significant effect on intended number of children. ${ }^{5}$ Finally, household position has a significant effect on lifetime fertility intentions: in all age groups the number of children currently wanted is highest among married women, but the differential between married women, women living with their parents, single women and women living in unmarried cohabitation is significantly smaller in the younger age groups. ${ }^{6}$

\section{Figure 1:}

Lifetime fertility intentions and realised fertility by age group, Flanders, 1991, women aged 20-39

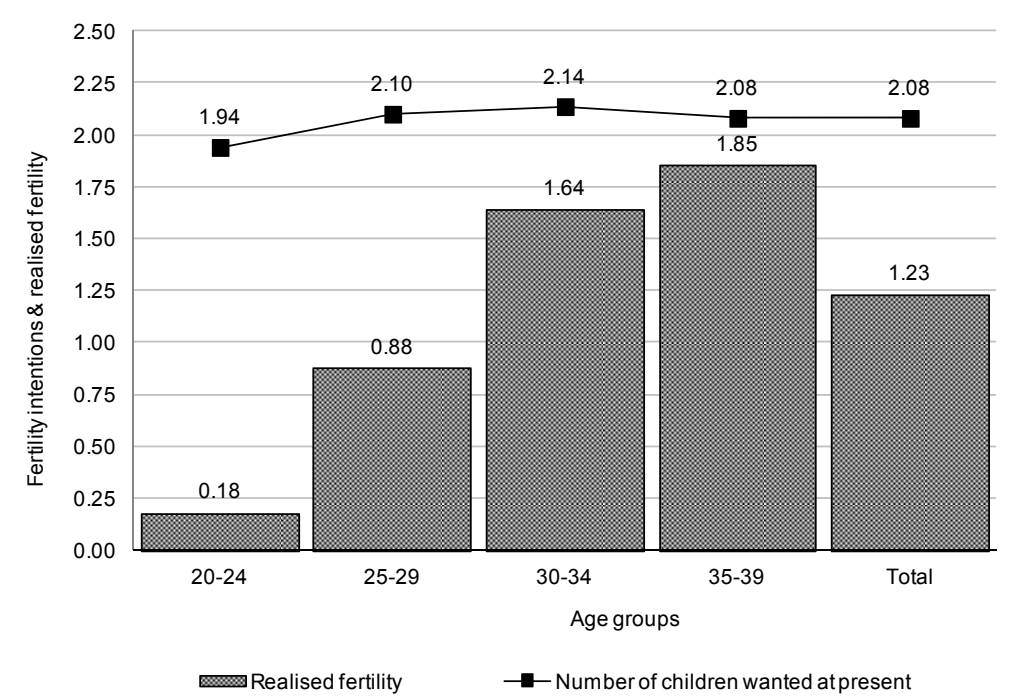

Source: Fertility and Family Survey, 1991, Flanders, calculation by authors.

Note: realised fertility pertains to the year of the survey and not to eventually achieved family size at the end of respondents' reproductive lives.

\footnotetext{
No significant effect of partner activity status was found on lifetime fertility intentions $(\mathrm{F}<1.000, \mathrm{p}>0.050)$.

6 The effect of household position on lifetime fertility intentions is significant with $\mathrm{F}=26.015$ and $\mathrm{p}<0.001$.
} 
Lifetime fertility intentions have the advantage of referring to completed fertility that cohorts may expect to realise by the end of their reproductive lifespan but the measure lacks a time reference to the moment these births are expected to be realised. For women with realised fertility being lower than their lifetime intentions, the FFS questionnaire probed into short-term fertility intentions (i.e. the intention of having a child in the next three years). In contrast to the number of children currently wanted, this indicator refers more explicitly to intentions regarding family formation in the near future. Two variants of this indicator were constructed, depending on the answers given by respondents. In the low variant only respondents who are decided are considered as having the intention to have a child within the next three years, whereas the high variant also includes respondents who expressed a higher degree of uncertainty regarding their short-term fertility intentions (Table 1). Although these measures lack an interpretation in terms of expected completed fertility, they provide clear evidence of differentiation of short-term fertility intentions by parity and level of education (Figure 2). The highest fertility intentions are found among childless women with 61.5 to 67.5 per cent intending to have a first child in the next three years. Fertility intentions are substantially lower at higher parities, with 31.8 to 35.6 per cent of the women with one child in 1991 intending to have a second birth in the next three years and 6.0 to 9.9 per cent of the women having two children intending to have a third birth.

Controlling for the number of children women have in 1991, fertility intentions vary significantly in terms of education and household position. Increasing education has a positive effect on short-term fertility intentions of women having no children or only one child in 1991, whereas the effect of education is positive but not significant on fertility intentions of women who already have two children in $1991 .^{7}$ Similarly, the educational level of partners has a significant positive effect on the intentions of having a first or second child, but no significant effect on the intention of having a third child. ${ }^{8}$ Household position only has a significant effect on the intention of having a first child, with married women having higher intentions than single women and women living in unmarried cohabitation. ${ }^{9}$ The activity status of women or their partners generally does not have a significant effect on the intention of having a child in the next three years, regardless of parity in 1991. Only among women who had one child in 1991, short-term fertility intentions were significantly higher for those working

7 The effect of education is significant on short-term intentions of having a first or second child with $\chi^{2}=23.047, \mathrm{p}<0.001$, and $\chi^{2}=52.279, \mathrm{p}<0.001$, respectively.

8 For short-term intentions of having a first or second child the educational level of the partner is significant with $\chi^{2}=20.917, \mathrm{p}<0.001$, and $\chi^{2}=36.538$, $\mathrm{p}<0.001$, respectively.

9 The effect of household position on short-term intentions of having a first child is significant with $\chi^{2}=37.250, \mathrm{p}<0.001$. 
part-time compared to women working full-time (regardless of educational level) and significantly lower among job seekers (also regardless of educational level). ${ }^{10}$

Table 1:

Number of children wanted at present and intentions of having a(nother) child in the next 3 years by parity and level of education (women and partners), activity status (women and partners) and household position, Flanders, 1991, women aged 20-39

\begin{tabular}{|c|c|c|c|c|c|c|c|c|}
\hline \multicolumn{5}{|c|}{$\begin{array}{l}\text { Number of children wanted } \\
\text { at present by age group: }\end{array}$} & \multicolumn{3}{|c|}{$\begin{array}{l}\text { Percentage that intends to have a child in } \\
\text { the next } 3 \text { years by parity }{ }^{(*)}\end{array}$} & \multirow[b]{2}{*}{$\mathbf{N}$} \\
\hline & 亡ั่ & ڤิ & 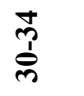 & ले & parity 0 & parity 1 & parity 2 & \\
\hline \multicolumn{9}{|c|}{ Educational level respondent } \\
\hline Low & 1.90 & 2.14 & 2.05 & 2.04 & $42.3(48.0)$ & $15.7(19.6)$ & $5.1(7.7)$ & 770 \\
\hline Medium & 1.84 & 1.97 & 1.99 & 1.92 & $62.8(67.9)$ & $34.4(38.1)$ & $4.9(8.6)$ & 1041 \\
\hline High & 2.10 & 2.20 & 2.37 & 2.36 & $66.7(73.7)$ & $52.8(56.7)$ & $8.5(14.0)$ & 898 \\
\hline \multicolumn{9}{|c|}{ Educational level partner } \\
\hline Low & $1.88^{\prime}$ & 2.06 & 2.06 & 2.00 & $50.0(56.0)$ & $20.8(26.2)$ & $6.7(8.8)$ & 697 \\
\hline Medium & 1.97 & 2.03 & 2.13 & 2.07 & $71.3(77.3)$ & $31.6(34.2)$ & $5.1(10.6)$ & 955 \\
\hline High & 2.25 & 2.29 & 2.33 & 2.36 & $71.3(75.9)$ & $54.1(55.7)$ & $6.9(11.5)$ & 703 \\
\hline \multicolumn{9}{|c|}{ Activity status respondent ${ }^{* * *}$} \\
\hline $\begin{array}{l}\text { Full-time } \\
\text { employed }\end{array}$ & 1.96 & 2.00 & 1.90 & 1.80 & $62.7(69.6)$ & $30.4(33.0)$ & $6.8(12.0)$ & 1464 \\
\hline $\begin{array}{l}\text { Part-time } \\
\text { employed } \\
\text { Job }\end{array}$ & 1.73 & 2.09 & 2.35 & 2.25 & $58.9(62.6)$ & $42.6(46.3)$ & $4.2(7.6)$ & 600 \\
\hline seeker & 1.98 & 2.16 & 2.19 & 1.98 & $62.1(63.6)$ & $17.6(25.0)$ & $7.4(9.5)$ & 299 \\
\hline Inactive & 2.23 & 2.62 & 2.46 & 2.60 & $36.4(40.9)$ & $30.9(36.8)$ & $6.4(9.6)$ & 346 \\
\hline \multicolumn{9}{|c|}{ Partner employment } \\
\hline $\begin{array}{l}\text { Not } \\
\text { employed }\end{array}$ & 2.18 & 2.24 & 2.06 & 1.96 & $71.9(73.7)$ & $35.0(40.0)$ & $8.7(8.7)$ & 125 \\
\hline Employed & 1.99 & 2.12 & 2.17 & 2.14 & $66.3(72.0)$ & $33.4(36.7)$ & $6.1(10.2)$ & 2294 \\
\hline \multicolumn{9}{|c|}{ Household position } \\
\hline $\begin{array}{l}\text { With } \\
\text { parents }\end{array}$ & 1.80 & 1.94 & 1.77 & 1.57 & $63.5(70.5)$ & $19.0(38.1)$ & $7.7(7.7)$ & 367 \\
\hline Single & 1.91 & 1.50 & 1.38 & 0.73 & $36.1(39.8)$ & - & - & 89 \\
\hline Married & 2.15 & 2.21 & 2.21 & 2.20 & $68.1(74.3)$ & $33.5(36.3)$ & $6.3(10.3)$ & 1879 \\
\hline Cohabiting & 1.86 & 1.80 & 1.93 & 1.56 & $60.3(65.4)$ & $34.6(38.5)$ & $7.5(12.5)$ & 268 \\
\hline Other & 1.30 & 1.95 & 1.99 & 2.16 & $18.2(18.2)$ & $13.9(22.2)$ & $0.0(0.0)$ & 106 \\
\hline Total & 1.94 & 2.10 & 2.14 & 2.08 & $61.5(67.5)$ & $31.8(35.6)$ & $6.0(9.9)$ & 2709 \\
\hline
\end{tabular}

Source: Fertility and Family Survey, 1991, Flanders, calculation by authors.

Note: $\left(^{*}\right)$ The first figure represents the low variant of the percentage intending to have a child in the next 3 years. The figure in brackets represents the high variant. $\left({ }^{* *}\right)$ Results based on 50 observations or less are in italics.

10 Activity status of women has a significant effect on short-term intentions of having a second child with $\chi^{2}=14.317, \mathrm{p}<0.010$. 
Figure 2:

Short-term intentions of having a child in the next 3 years: distribution of answer categories by parity and level of education, Flanders, 1991, women aged 20-39

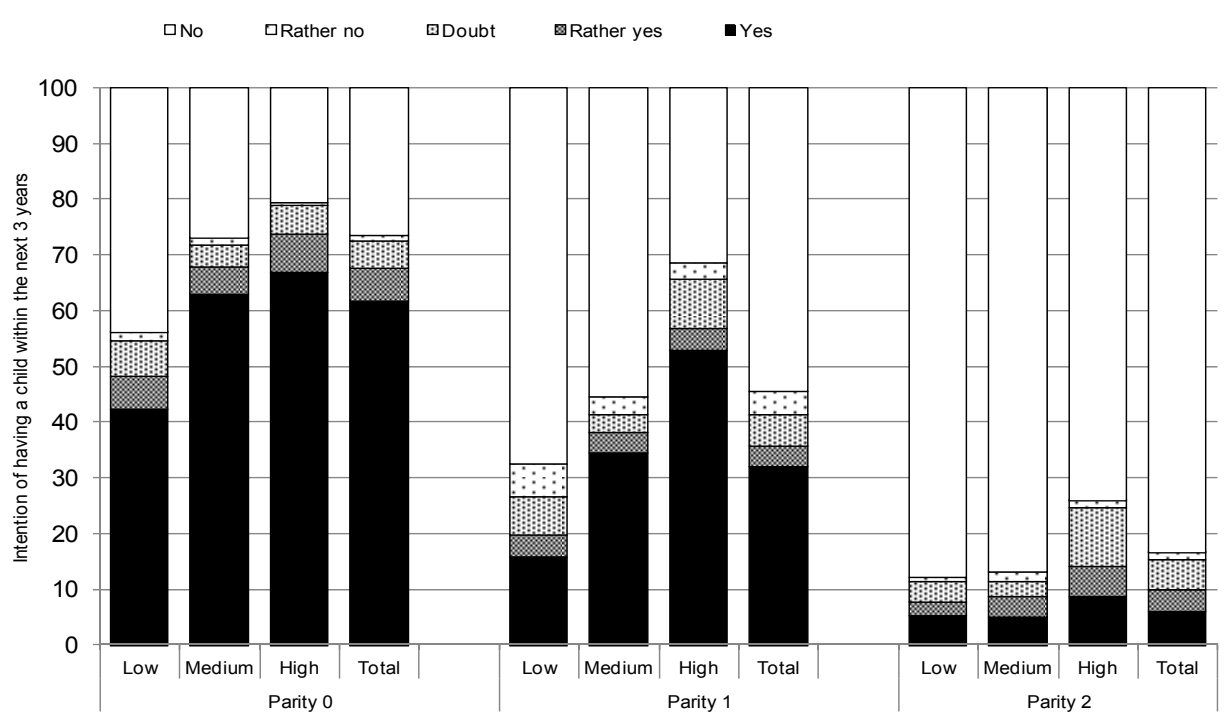

Source: Fertility and Family Survey, 1991, Flanders, calculation by authors.

\subsection{Fertility outcomes}

Compared to the high fertility intentions recorded in the FFS in 1991, the actual fertility outcomes in the 3-year period after 1991 are generally lower, particularly among childless women (Figure 3). The proportion of childless women having their first birth between 1992 and 1994 is limited to 26.8 per cent, compared to fertility intentions ranging from 61.5 to 67.5 per cent in the FFS. Further breakdown of entry into parenthood by level of education shows that highly educated women are more likely to realise a first birth in the next three years than women with lower educational levels. The positive gradient between education and entry into parenthood largely reflects the catching-up behaviour of highly educated women who had postponed fertility well into their late twenties and were entering their prime childbearing years during the observation window (Kravdal 2002; Kreyenfeld 2002). With respect to second and especially third births the gap between intentions and fertility is substantially lower. Fertility outcomes for second births approximate the low variant of intentions measured in the FFS, exceeding it in the case of third births. Among women having already one child in 1991, 23.5 per cent realise a second birth between 1992 and 1994, compared to intentions ranging from 31.8 to 35.6 per cent. Similarly, 8.7 per cent of the women having two children in 1991 realise a third birth in the subsequent 3 -year period, compared to intentions ranging from 6.0 to 9.9 per cent. Consistent 
with earlier findings, highly educated women progress more frequently to a second and third birth than less educated women. Overall, the aggregate consistency between intentions and fertility is considerably lower for entry into parenthood than for second and third births. A number of explanations seem plausible for the larger gap between intentions and behaviour among childless women. First, given that these women have no prior experience with family formation, intentions are likely to be more abstract and less realistic (RégnierLoilier 2006). Second, the short economic revival in 1990 was followed by labour market conditions deteriorating rapidly in the next few years, which might have substantially delayed entry into parenthood (Neels 2010). Thirdly, due to a nonnegligible waiting time to pregnancy, which can be one year or longer in some couples, some of the intended births would not have occurred even if the couple behaved in consistency with their intentions (Juul et al. 1999).

Figure 3:

Percentage of women aged 20-39 in 1991 having a child in the next 3 years by parity and level of education, Flanders

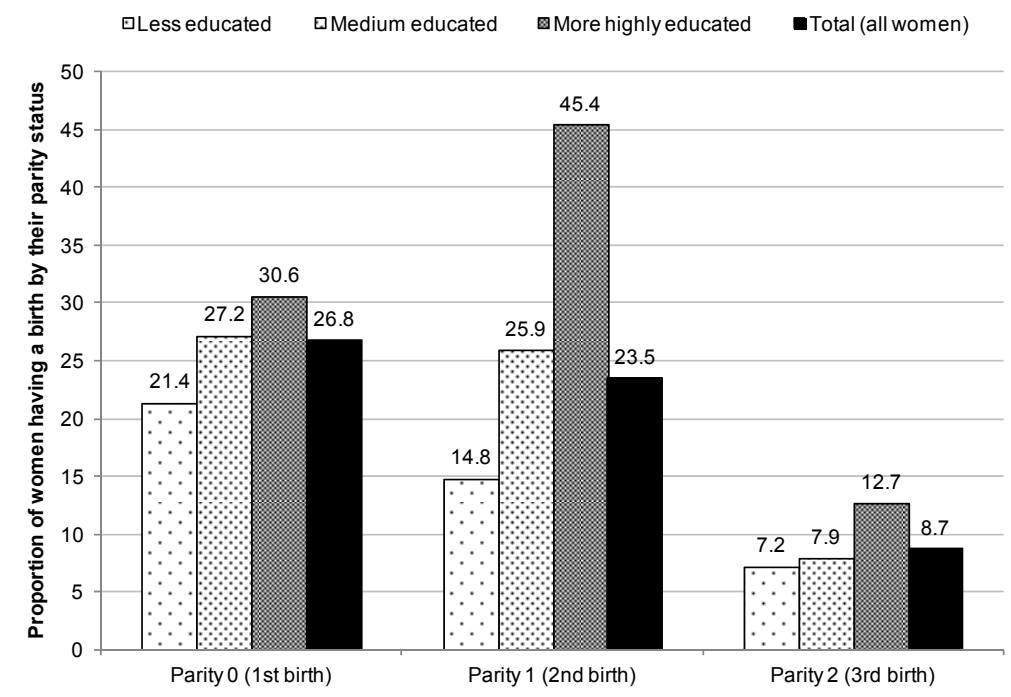

Source: Statistics Belgium, 1991 and 2001 census, calculation by authors

Further insight in the mechanisms behind the positive educational gradient in parity progression is gained by drawing up the profile of these educational groups in terms of household position, activity status and partner characteristics (Table 2) and subsequently mapping how these characteristics affect birth hazards in the subsequent 3-year period (Table 3a-3c). All analyses pertain to women who already left education, with their level of education corresponding to the situation on 1 March 1991. 
Table 2:

Household position, activity status (women and partners) and partner education on 1 March 1991 by parity and level of education, Flanders, women aged 20-39

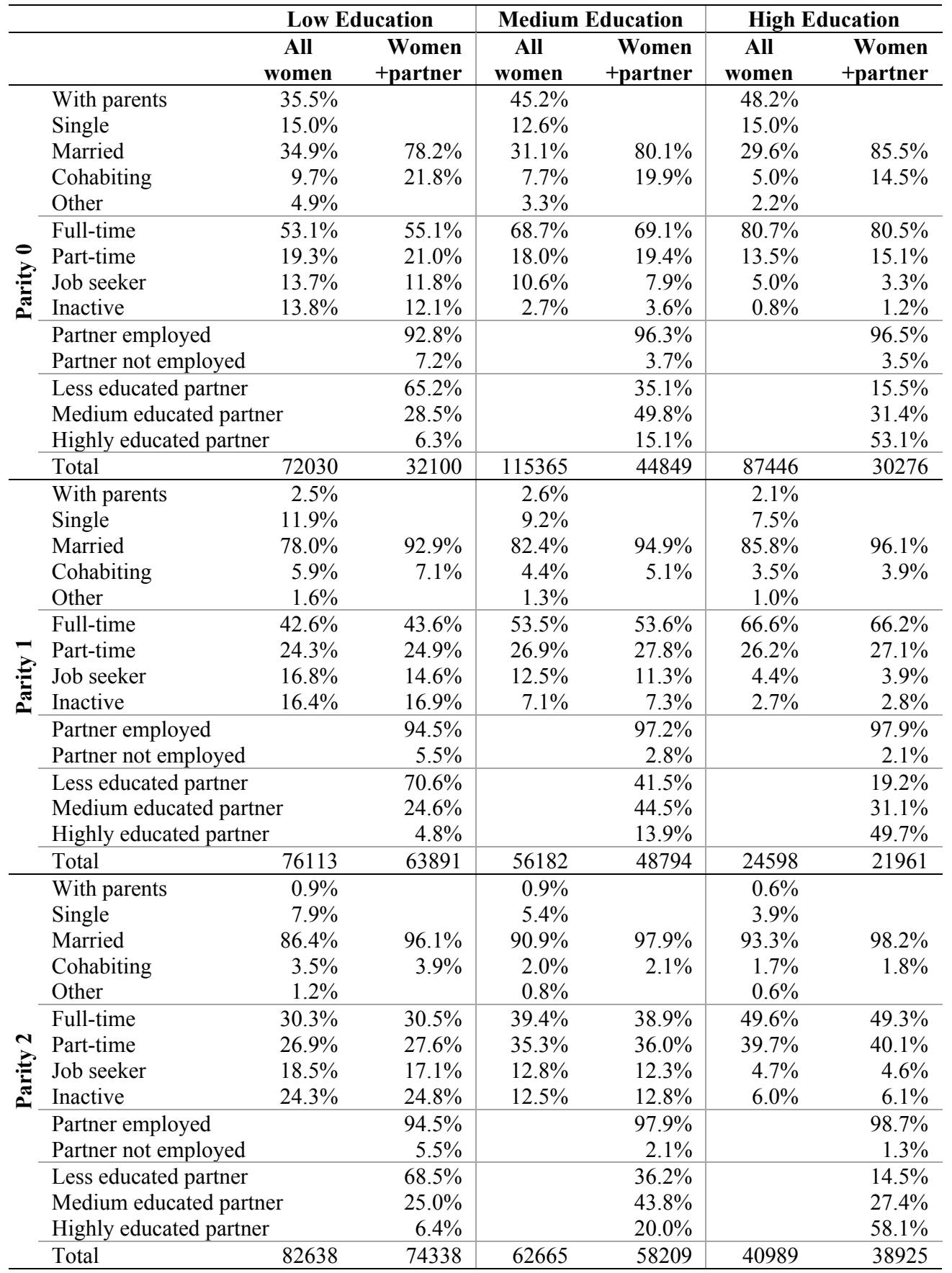

Source: Statistics Belgium, 1991 and 2001 census, calculation by authors 


\section{Transition to first births}

Among childless women, household positions are clearly differentiated in terms of education. Less and medium-educated women more frequently live in a union, whereas highly educated women more often live with their parents, reflecting the delaying impact of a prolonged stay in education on home leaving and union formation. ${ }^{11}$ Marriage is the most common household type in all educational groups among women living with a partner, but a substantial share of the less educated women are also found in unmarried cohabitation. Consistent with the less stable character of non-marital living arrangements and the fact that such households more frequently attract women who are less child and familyoriented, first-birth hazards are significantly lower among single women and women living in unmarried cohabitation, with the negative effect becoming more articulated among women with higher levels of education. In line with previous research for Flanders, the connection between parenthood and marriage is found to be strongest among highly educated women (Van Bavel and De Wachter 2007; Neels and De Wachter 2010), suggesting that these women have more traditional views on family formation once childbearing comes into the picture (Sobotka 2008).

Important educational differentials also emerge with respect to activity status. Highly educated women are more likely to be full-time employed than less and medium-educated women. Among the latter groups, a larger share is inactive or seeking employment. Also part-time employment is more prevalent among less educated women. In all educational groups, women who are active in the labour market show the highest first-birth hazards. There are no significant differences between full-time and part-time employment. Compared to women working fulltime, job seekers and economically inactive women have significantly lower firstbirth hazards. ${ }^{12}$ The negative effect of unemployment and economic inactivity is more articulated among highly educated women, suggesting that these educational groups consider it particularly important to secure a position in the labour market before starting their childbearing career (Neels 2010; Neels and De Wachter 2010).For women living with a partner, the data reveal a clear pattern of educational homogamy: less educated women are much more likely to cohabit with a less educated partner while the reverse holds for highly educated women. In all educational groups, first-birth hazards increase together with partner's

11 The census reflects the household composition in the national registry and unmarried cohabitation is undercounted as a result. Particularly among women in education, a substantial number is likely to live with a partner while being officially registered in the parental household.

12 The negative effect of inactivity on first-birth hazards is not surprising, however. Given that before family formation women who are inactive in the labour market may be in poor health or have other non-family related reasons for their inactivity, it is not likely that inactivity would lead to higher fertility. Only after having a first child may economic inactivity signal a greater child or family orientation and higher intentions of having another child. 
education. Finally, unemployment among male partners is generally low, but nevertheless more frequent among partners of less educated women. In all educational groups unemployment of partners exerts a negative effect on firstbirth hazards. The negative effect of partner unemployment and the positive effect of partner education on entry into parenthood are more articulated among less educated women. Compared to highly educated women, entry into parenthood among less educated women is more dependent on the activity status and income of their partners.

Table 3a:

Effect (hazard ratio) of household position, activity status and partner characteristics in 1991 on first-birth hazards in 1992-1994 by level of education, Flanders, childless women aged 20-39

\begin{tabular}{|c|c|c|c|c|c|c|}
\hline & \multicolumn{2}{|c|}{ Low Education } & \multicolumn{2}{|c|}{ Medium Education } & \multicolumn{2}{|c|}{ High Education } \\
\hline & $\begin{array}{l}\text { All } \\
\text { women }\end{array}$ & $\begin{array}{l}\text { Women } \\
\text { +partner }\end{array}$ & $\begin{array}{l}\text { All } \\
\text { women }\end{array}$ & $\begin{array}{l}\text { Women } \\
+ \text { partner }\end{array}$ & $\begin{array}{l}\text { All } \\
\text { women }\end{array}$ & $\begin{array}{l}\text { Women } \\
+ \text { partner }\end{array}$ \\
\hline Intercept & $0.12 * * *$ & $0.14 * * *$ & $0.03 * * *$ & $0.06^{* * *}$ & $0.01 * * *$ & $0.01 * * *$ \\
\hline \multicolumn{7}{|c|}{ Period effect (time-varying) } \\
\hline P1992 & - & - & - & - & - & - \\
\hline P1993 & $1.05^{*}$ & $0.92 * *$ & $1.10 * * *$ & $0.93 * * *$ & $1.18 * * *$ & 0.98 \\
\hline P1994 & $1.11 * * *$ & $0.88 * * *$ & $1.17 * * *$ & $0.85 * * *$ & $1.31 * * *$ & $0.90 * * *$ \\
\hline \multicolumn{7}{|c|}{ Duration since age 15 (time-varying) } \\
\hline Linear & $1.23 * * *$ & $1.23 * * *$ & $1.46 * * *$ & $1.36 * * *$ & $1.84 * * *$ & $1.72 * * *$ \\
\hline Quadratic & $0.99 * * *$ & $0.99 * * *$ & $0.98 * * *$ & $0.98 * * *$ & $0.98 * * *$ & $0.98 * * *$ \\
\hline \multicolumn{7}{|c|}{ Household position in 1991 (time-constant) } \\
\hline With parents & $0.30 * * *$ & & $0.28 * * *$ & & $0.24 * * *$ & \\
\hline Single & $0.54 * * *$ & & $0.41 * * *$ & & $0.29 * * *$ & \\
\hline Married & - & - & - & - & - & - \\
\hline Cohabiting & $0.67 * * *$ & $0.67 * * *$ & $0.59 * * *$ & $0.60 * * *$ & $0.54 * * *$ & $0.57 * * *$ \\
\hline Other & $0.49 * * *$ & & $0.49 * * *$ & & $0.42 * * *$ & \\
\hline \multicolumn{7}{|c|}{ Activity status in 1991 (time-constant) } \\
\hline Full-time & - & - & - & - & - & - \\
\hline Part-time & 0.97 & 0.98 & 0.99 & 0.97 & 1.01 & 1.01 \\
\hline Job seeker & $0.89 * * *$ & $0.87 * * *$ & $0.87 * * *$ & $0.90 * * *$ & $0.70 * * *$ & $0.73 * * *$ \\
\hline Inactive & $0.61 * * *$ & $0.79 * * *$ & $0.85 * * *$ & $0.81 * * *$ & $0.75 * *$ & 0.83 \\
\hline \multicolumn{7}{|c|}{$\begin{array}{l}\text { Activity status male partner in } 1991 \\
\text { (time-constant) }\end{array}$} \\
\hline Employed & & - & & - & & - \\
\hline Not employed & & $0.90 *$ & & $0.82 * * *$ & & 0.94 \\
\hline \multicolumn{7}{|c|}{$\begin{array}{l}\text { Education male partner in } 1991 \\
\text { (time-constant) }\end{array}$} \\
\hline Low & & - & & - & & - \\
\hline Medium & & $1.07 * *$ & & $1.09 * * *$ & & $1.10 * * *$ \\
\hline High & & $1.42 * * *$ & & $1.32 * * *$ & & $1.26 * * *$ \\
\hline N Events & 15394 & 8797 & 31404 & 18063 & 26738 & 15575 \\
\hline N Person-periods & s 198713 & 85286 & 312293 & 111979 & 234058 & 71161 \\
\hline$-2 \mathrm{LL}$ & 97015 & 49278 & 187771 & 91385 & 149071 & 69658 \\
\hline
\end{tabular}

Source: Statistics Belgium, 1991 and 2001 census, calculation by authors

Significance levels: $\mathrm{p}<.05(*), \mathrm{p}<.01(* *), \mathrm{p}<.001(* * *)$ 


\section{Transition to second births}

Among women who entered parenthood, marriage is the dominant household position in all educational groups, but particularly so among highly educated women. Less educated women are more likely to be single or to live in unmarried cohabitation.

Table 3b:

Effect (hazard ratio) of household position, activity status and partner characteristics in 1991 on second-birth hazards in 1992-1994 by level of education, Flanders, women aged 20-39 having 1 child

\begin{tabular}{|c|c|c|c|c|c|c|}
\hline & \multicolumn{2}{|c|}{ Low Education } & \multicolumn{2}{|c|}{ Medium Education } & \multicolumn{2}{|c|}{ High Education } \\
\hline & $\begin{array}{l}\text { All } \\
\text { women }\end{array}$ & $\begin{array}{l}\text { Women } \\
\text { +partner }\end{array}$ & $\begin{array}{l}\text { All } \\
\text { women }\end{array}$ & $\begin{array}{l}\text { Women } \\
+ \text { partner }\end{array}$ & $\begin{array}{l}\text { All } \\
\text { women }\end{array}$ & $\begin{array}{l}\text { Women } \\
+ \text { partner }\end{array}$ \\
\hline Intercept & $1.80 * * *$ & $1.76 * * *$ & $1.20 *$ & 0.98 & 1.35 & 0.90 \\
\hline $\begin{array}{l}\text { Period effect (tim } \\
\text { P1992 } \\
\text { P1993 } \\
\text { P1994 }\end{array}$ & $\begin{array}{l}\text { e-varying } \\
- \\
1.07 * * \\
0.96\end{array}$ & $\begin{array}{l}- \\
1.06 * \\
0.94 *\end{array}$ & $\begin{array}{l}- \\
1.12 * * * \\
0.90 * * *\end{array}$ & $\begin{array}{l}- \\
1.12 * * * \\
0.87 * * *\end{array}$ & $\begin{array}{l}- \\
1.21 * * * \\
0.99\end{array}$ & $\begin{array}{l}- \\
1.18 * * * \\
0.95\end{array}$ \\
\hline $\begin{array}{l}\text { Duration since fir } \\
\text { Linear } \\
\text { Quadratic }\end{array}$ & $\begin{array}{l}\text { rst child } \\
0.71^{* * *} \\
1.00^{*}\end{array}$ & $\begin{array}{l}\text { varying) } \\
0.72 * * * \\
1.00\end{array}$ & $\begin{array}{l}0.72 * * * \\
1.00 *\end{array}$ & $\begin{array}{l}0.76 * * * \\
0.99 * * *\end{array}$ & $\begin{array}{l}0.73 * * * \\
0.99 * * *\end{array}$ & $\begin{array}{l}0.83 * * * \\
0.98 * * *\end{array}$ \\
\hline $\begin{array}{l}\text { Age at first child } \\
\text { Linear } \\
\text { Quadratic }\end{array}$ & $\begin{array}{l}\text { (time-var) } \\
0.90^{* * *} \\
1.00\end{array}$ & $\begin{array}{l}0.90 * * * \\
1.00\end{array}$ & $\begin{array}{l}0.99 \\
1.00 * * *\end{array}$ & $\begin{array}{l}1.00 \\
1.00 * * *\end{array}$ & $\begin{array}{l}1.07 * * \\
0.99 * * *\end{array}$ & $\begin{array}{l}1.06 * \\
0.99 * * *\end{array}$ \\
\hline $\begin{array}{l}\text { Household positio } \\
\text { With parents } \\
\text { Single } \\
\text { Married } \\
\text { Cohabiting } \\
\text { Other }\end{array}$ & $\begin{array}{l}\text { on in } 199 \\
0.70 * * * \\
1.01 \\
- \\
0.98 \\
0.96\end{array}$ & $\begin{array}{l}\text { ne-constant } \\
- \\
0.98\end{array}$ & $\begin{array}{l}0.66 * * * \\
0.70 * * * \\
- \\
0.78 * * * \\
1.00\end{array}$ & $-\overline{0.81 * * *}$ & $\begin{array}{l}0.61 * * * \\
0.57 * * * \\
- \\
0.73 * * * \\
0.93\end{array}$ & - $0.76 * * *$ \\
\hline $\begin{array}{l}\text { Activity status in } \\
\text { Full-time } \\
\text { Part-time } \\
\text { Job seeker } \\
\text { Inactive }\end{array}$ & $\begin{array}{l}1991 \text { (tim } \\
- \\
1.01 \\
0.95 * \\
1.05\end{array}$ & $\begin{array}{l}\text { nstant) } \\
- \\
1.01 \\
0.96 \\
1.08^{*}\end{array}$ & $\begin{array}{l}- \\
1.06 * * \\
0.94^{*} \\
1.05\end{array}$ & $\begin{array}{l}- \\
1.06 * * \\
0.97 \\
1.07\end{array}$ & $\begin{array}{l}- \\
1.07 * * \\
0.90 * \\
0.98\end{array}$ & $\begin{array}{l}- \\
1.08 * * \\
0.93 \\
1.00\end{array}$ \\
\hline $\begin{array}{l}\text { Activity status ma } \\
\text { (time-constant) } \\
\text { Employed } \\
\text { Not employed }\end{array}$ & ale partne & $\begin{array}{l}1991 \\
- \\
0.98\end{array}$ & & $\begin{array}{l}- \\
0.98\end{array}$ & & $\begin{array}{l}- \\
0.93\end{array}$ \\
\hline $\begin{array}{l}\text { Education male p } \\
\text { (time-constant) } \\
\text { Low } \\
\text { Medium } \\
\text { High }\end{array}$ & oartner in & $\begin{array}{l}- \\
1.08 * * \\
1.49 * * *\end{array}$ & & $\begin{array}{l}- \\
1.18 * * * \\
1.65 * * *\end{array}$ & & $\begin{array}{l}- \\
1.14 * * * \\
1.56 * * *\end{array}$ \\
\hline $\begin{array}{l}\text { N Events } \\
\text { N Person-periods } \\
-2 \mathrm{LL}\end{array}$ & $\begin{array}{r}11237 \\
213591 \\
70389 \\
\end{array}$ & $\begin{array}{r}9530 \\
178956 \\
58044 \\
\end{array}$ & $\begin{array}{r}14532 \\
148648 \\
77139 \\
\end{array}$ & $\begin{array}{r}13217 \\
128053 \\
67908 \\
\end{array}$ & $\begin{array}{l}11168 \\
57456 \\
44031 \\
\end{array}$ & $\begin{array}{l}10573 \\
50324 \\
40165 \\
\end{array}$ \\
\hline
\end{tabular}

Source: Statistics Belgium, 1991 and 2001 census, calculation by authors

Significance levels: $\mathrm{p}<.05(*), \mathrm{p}<.01(* *), \mathrm{p}<.001(* * *)$ 
Similar to the results for childless women, married mothers experience the highest second-birth hazards. Hazards are significantly lower for women living with their parents, single women and women living in unmarried cohabitation (except for less educated groups). The connection between marriage and parenthood is again more articulated among highly educated women, whereas non-marital living arrangements more frequently lead to family formation among women with lower levels of education. In line with expectations, the negative effect of living in non-marital living arrangements is less pronounced for second than for first births. This partly reflects the fact that couples who form a new union after divorce of separation often try to cement their new union by having a baby.

Entry into parenthood has a clear effect on activity status. In all educational groups the proportion of women working full-time declines by 10 to 15 percentage points whereas the proportion of women working part-time has increases accordingly. Among less educated women, entry into parenthood is associated with a further weakening of their labour market position, with a higher proportion of women entirely retreating from the labour market. Women in parttime employment now realise the highest second-birth hazards, with the positive effect being more pronounced among highly educated women. Consistent with expectations, the negative effect of job seeking is less articulated for second than for first births, yet the effect is still somewhat stronger at higher educational levels. Inactive women with low and medium levels of education report higher second-birth hazards than women in full-time employment. These findings support the notion that the retreat from the labour market after having a first child increasingly involves a selection of more child- and family-oriented women prepared to (partially) forgo labour force participation in favour of continued childbearing.

Also partner characteristics play an important role for second births. The positive effect of the partner's educational level on second-birth hazards is more pronounced than on entry into parenthood, particularly among women with medium to high educational levels. The latter suggests that among women who manage to combine labour force participation and family formation, the income effect results in more frequent progression to a second child. Partner activity status, however, has no significant effect on second-birth hazards. Presumably this is due to the limited amount of variation in activity status of partners among women having one child.

\section{Transition to third births}

The variation in the household position is limited among women having two children. The vast majority of the women live together with a partner in a marital union. Single-person households and non-marital unions are somewhat more prevalent however among less educated women. The results of the hazard models suggest that women living in non-marital households experience the highest third- 
birth hazards. This finding is likely to reflect the higher fertility intentions of women entering a new union after separation or divorce.

Table 3c:

Effect (hazard ratio) of household position, activity status and partner characteristics in 1991 on third-birth hazards in 1992-1994 by level of education, Flanders, women aged 20-39 with 2 children

\begin{tabular}{|c|c|c|c|c|c|c|}
\hline & \multicolumn{2}{|c|}{ Low Education } & \multicolumn{2}{|c|}{ Medium Education } & \multicolumn{2}{|c|}{ High Education } \\
\hline & $\begin{array}{l}\text { All } \\
\text { women }\end{array}$ & $\begin{array}{l}\text { Women } \\
\text { + partner }\end{array}$ & $\begin{array}{l}\text { All } \\
\text { women } \\
\end{array}$ & $\begin{array}{l}\text { Women } \\
+ \text { partner }\end{array}$ & $\begin{array}{l}\text { All } \\
\text { women }\end{array}$ & $\begin{array}{l}\begin{array}{l}\text { Women } \\
+ \text { partner }\end{array} \\
\end{array}$ \\
\hline Intercept & $1.46^{* *}$ & $1.57 * * *$ & $1.64 * *$ & $1.54 *$ & $2.33 * *$ & $2.32 *$ \\
\hline $\begin{array}{l}\text { Period effect (tim } \\
\text { P1992 } \\
\text { P1993 } \\
\text { P1994 }\end{array}$ & $\begin{array}{l}\text { ne-varying) } \\
- \\
1.00 \\
0.98\end{array}$ & $\begin{array}{l}- \\
0.98 \\
0.97\end{array}$ & $\begin{array}{l}- \\
1.01 \\
0.92 *\end{array}$ & $\begin{array}{l}- \\
1.00 \\
0.90^{*}\end{array}$ & $\begin{array}{l}- \\
1.11 * * \\
1.00\end{array}$ & $\begin{array}{l}- \\
1.11 * * \\
1.02\end{array}$ \\
\hline $\begin{array}{l}\text { Duration since se } \\
\text { Linear } \\
\text { Quadratic }\end{array}$ & $\begin{array}{l}\text { econd child } \\
0.79^{* * *} \\
1.00^{* * *}\end{array}$ & $\begin{array}{l}\text { ime-varying) } \\
0.79^{* * *} \\
0.99^{* * *}\end{array}$ & $\begin{array}{l}0.73^{* * *} \\
1.00\end{array}$ & $\begin{array}{l}0.74^{* * * *} \\
1.00\end{array}$ & $\begin{array}{l}0.73 * * * \\
0.99 * * *\end{array}$ & $\begin{array}{l}0.77 * * * \\
0.99 * * *\end{array}$ \\
\hline $\begin{array}{l}\text { Age at second ch } \\
\text { Linear } \\
\text { Quadratic }\end{array}$ & $\begin{array}{l}\text { ild (time-val } \\
0.78^{* * *} \\
1.00^{* * *}\end{array}$ & $\begin{array}{l}\text { ing) } \\
0.78^{* * *} \\
1.00^{* * *}\end{array}$ & $\begin{array}{l}0.80^{* * *} \\
1.00^{*}\end{array}$ & $\begin{array}{l}0.80^{* * * *} \\
1.00\end{array}$ & $\begin{array}{l}0.86^{* *} \\
1.00\end{array}$ & $\begin{array}{l}0.82 * * * \\
1.00\end{array}$ \\
\hline $\begin{array}{l}\text { Household positi } \\
\text { With parents } \\
\text { Single } \\
\text { Married } \\
\text { Cohabiting } \\
\text { Other }\end{array}$ & $\begin{array}{l}\text { ion in } 1991 \text { (1 } \\
1.00 \\
1.73^{* * *} \\
- \\
1.60^{* * *} \\
1.14\end{array}$ & $\begin{array}{l}\text { ime-constant) } \\
- \\
1.55^{* * *}\end{array}$ & $\begin{array}{l}1.09 \\
1.58 * * * \\
- \\
1.70 * * * \\
1.28 *\end{array}$ & $-\overline{1.71 * * *}$ & $\begin{array}{l}1.25 \\
1.05 \\
- \\
1.40 * * \\
1.04 \\
\end{array}$ & $-\overline{1.44 * * *}$ \\
\hline $\begin{array}{l}\text { Activity status in } \\
\text { Full-time } \\
\text { Part-time } \\
\text { Job seeker } \\
\text { Inactive }\end{array}$ & $\begin{array}{l}1991 \text { (time- } \\
- \\
1.09^{*} \\
1.20^{* * *} \\
1.48^{* * *}\end{array}$ & $\begin{array}{l}\text { onstant) } \\
- \\
1.10^{*} \\
1.19 * * * \\
1.48 * * *\end{array}$ & $\begin{array}{l}- \\
1.14 * * * \\
1.11 * \\
1.32 * * *\end{array}$ & $\begin{array}{l}- \\
1.15^{* * *} \\
1.13^{* *} \\
1.36^{* * *}\end{array}$ & $\begin{array}{l}- \\
1.19 * * * \\
1.18^{* *} \\
1.50 * * *\end{array}$ & $\begin{array}{l}- \\
1.20^{* * *} \\
1.21 * * \\
1.50^{* * *}\end{array}$ \\
\hline $\begin{array}{l}\text { Activity status ma } \\
\text { (time-constant) } \\
\text { Employed } \\
\text { Not employed }\end{array}$ & ale partner $i$ & $\begin{array}{l}1991 \\
- \\
1.29 * * *\end{array}$ & & $-\overline{1.23 *}$ & & $\begin{array}{l}- \\
1.07\end{array}$ \\
\hline $\begin{array}{l}\text { Education male } \\
\text { (time-constant) } \\
\text { Low } \\
\text { Medium } \\
\text { High } \\
\end{array}$ & partner in 19 & $\begin{array}{l}- \\
0.94 \\
1.28 * * *\end{array}$ & & $\begin{array}{l}- \\
1.07 * \\
1.48^{* * *}\end{array}$ & & $\begin{array}{l}- \\
1.02 \\
1.63 * * *\end{array}$ \\
\hline $\begin{array}{l}\text { N Events } \\
\text { N Person-periods } \\
\text {-2LL }\end{array}$ & $\begin{array}{r}5950 \\
\text { s } \quad 240553 \\
47479 \\
\end{array}$ & $\begin{array}{r}5111 \\
216636 \\
41117 \\
\end{array}$ & $\begin{array}{r}4955 \\
181731 \\
40241 \\
\end{array}$ & $\begin{array}{r}4538 \\
168822 \\
36673 \\
\end{array}$ & $\begin{array}{r}5211 \\
116200 \\
36698 \\
\end{array}$ & $\begin{array}{r}5018 \\
110267 \\
34867 \\
\end{array}$ \\
\hline
\end{tabular}

Source: Statistics Belgium, 1991 and 2001 census, calculation by authors

Significance levels: $\mathrm{p}<.05(*), p<.01(* *), p<.001(* * *)$ 
After having a second child the activity status of women changes considerably. Full-time employment continues to be the most common activity position in all educational groups, but the proportion of women engaged in fulltime work declines further compared to women having one child. Highly educated women more frequently resort to part-time work while less educated women more frequently retreat from the labour market entirely. Women in fulltime employment show the lowest third-birth hazards. Although it is not possible with the data at hand to determine whether the (partial) retreat from the labour market reflects a voluntary decision, the results are again likely to reflect the selfselection of more child- and family-oriented women into unemployment and economic inactivity.

Finally, the effect of partner characteristics becomes more articulated here, particularly among highly educated women. The distribution of partner's activity status indicates that the majority of partners are employed in all three educational groups. In contrast to expectations, partners who are not employed are associated with higher third-birth hazards, particularly among less educated women. However, this concerns only a small group of partners.

\section{Differential uptake of child care}

The stronger attachment of highly educated women to the labour market after parenthood suggests that they have access to acceptable child care arrangements that alleviate the role incompatibility between motherhood and labour force participation. The FFS provides additional information on use of informal and formal child care that allows to document educational differentials in the uptake of such arrangements (Figure 4). The results for Flanders in 1991 indicate that the majority of women make use of (in)formal child care regardless of parity and level of education, but that educational differentials are nevertheless pronounced: among women having one or two children, 80.1 to 84.8 per cent, respectively, of the highly educated women make use of child care whereas these figures range from 72.3 to 72.7 per cent for medium-educated women and 60.2 to 61.3 per cent for less educated women. The educational differentials in child care uptake predominantly reflect a differential use of formal care arrangements: the percentage of women with one child relying on kindergartens and day nurseries ranges from 19.9 per cent among less educated women to 44.1 per cent among the highly educated. Among women having two children, educational differentials in uptake of formal child care range from 26.2 to 55.6 per cent. Although the data at hand do not allow to establish the causal direction, the differential retreat from the labour market corresponds to marked educational differentials in (particularly) formal child care. 
Figure 4:

Use of formal and informal child care arrangements by parity and level of education, Flanders, 1991, women aged 20-39

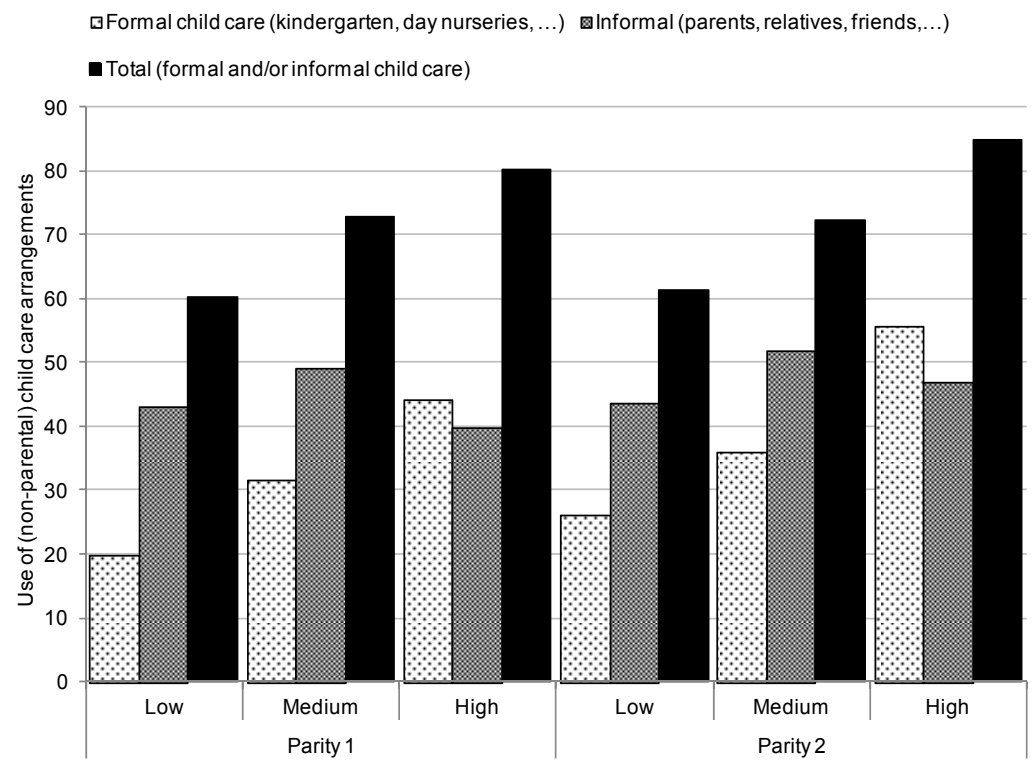

Source: Fertility and Family Survey, 1991, Flanders, calculation by authors

\section{Conclusions}

The gap between fertility intentions and completed fertility has raised questions why women do not achieve their desired level of fertility. Frequently cited explanations point in the direction of high opportunity costs of parenthood, the role played by economic recession and the increasing popularity of more unstable living arrangements that have affected family formation indirectly. Focusing on the case of Flanders in the early 1990s we use data from the FFS of 1991 and longitudinal microdata from the Belgian censuses of 1991 and 2001 to i) analyse the level of fertility intentions and the patterning of intentions in terms of socioeconomic characteristics and ii) compare intentions at an aggregate level to the fertility outcomes in a prospective study in order to identify factors associated with high versus low fertility. Given the central role attributed to education in various explanations of fertility decline, we focus specifically on educational differentials in intentions and outcomes and how the latter are related to labour market outcomes, household positions and uptake of (in)formal child care.

The results of the FFS indicate that lifetime fertility intentions in Flanders in the early 1990s are situated around the replacement level. The breakdown of fertility intentions by level of education shows that highly educated women report 
higher lifetime and short-term intentions than less educated women. The proportion of women having a child in the 3-year period following the 1991 census is generally lower, however, than what short-term intentions measured in the FFS suggest, particularly in the case of first births. The breakdown of fertility by level of education indicates that entry into parenthood as well as progression to a second and third birth is more frequent among highly educated women. Although educational differentials in childlessness decreased markedly among cohorts born between 1930 and 1960, and differentials have disappeared for women with short-type tertiary education, childlessness continues to be somewhat more prevalent among women with long-type tertiary education in recent birth cohorts (Gadeyne et al. forthcoming). As a result, the positive effect of education on first-birth hazards in our analysis largely reflects a time-squeeze effect (Kreyenfeld 2002). Highly educated women leave the education system much later in life, often at age 25 or older, and thus have fewer years to have a first birth than less educated women. The shorter time they have left to 'catch up' thus results in higher first-birth hazards in a limited age range. For progression to second and third births, however, the cross-sectional results based on the period between 1992-94 are consistent with educational differentials in cohort parity progression (Gadeyne et al. forthcoming).

The comparison of aggregate fertility intentions with fertility outcomes suggests that access to stable employment and to provisions that support the combination of child care and labour force participation have become important conditions for fertility intentions to materialise, particularly for highly educated women. For the latter group, the highest hazards of becoming a mother are associated with full-time employment, marriage to a highly educated partner and partner employment, i.e. dual-earner households. Highly educated women frequently make use of (in)formal child care, which allows them to remain strongly attached to the labour market, even when having one or two children. For less educated women the results show different pathways in family formation. Although the highest hazards of parenthood are associated with marriage and fulltime employment here as well, less educated women in alternative living arrangements and less favourable labour market positions show higher first-birth hazards than highly educated women. Homogamy to less educated partners as well as higher unemployment risks of these partners reduces first-birth hazards. For less educated women entry into parenthood and progression to a second or third child more often entails a further weakening of their position in the labour market, as they more frequently move into unemployment or economic inactivity. This (partial) retreat of less educated women from the labour market is associated with their significantly lower uptake of (in)formal child care compared to highly educated women.

Although gender equity and the compatibility of worker and caregiver roles have long been identified as variables relevant for policy, our results suggest that educational differentials in fertility intentions as well as differential access to 
stable employment and uptake of child care require further attention, given their relevance for both fertility trends and the socio-economic position of women concerned. Although the results discussed here pertain to the early 1990s, recent research on differential uptake of child care arrangements and parental leave in Flanders indicates that these issues have remained highly relevant (Desmet et al. 2007; Ghysels et al. 2009).

\section{Acknowledgments}

An early version of the article was presented at the international conference "From Intentions to Behaviour: Reproductive Decision-Making in a Macro-Micro Perspective" organised by the Vienna Institute of Demography on 2-3 December 2010. We thank reviewers of earlier versions for their valuable suggestions and comments.

\section{References}

Allison, P.D. 1982. Discrete-time methods for the analysis of event histories. Sociological Methodology 13: 61-98.

Becker, G.S. 1981. A treatise on the family. Harvard: Harvard University Press.

Becker, G.S. and H.G. Lewis 1973. On the interaction between the quantity and quality of children. The Journal of Political Economy 81(2): 279-288.

Berrington, A. 2004. Perpetual postponers. Women's, men's and couples' fertility intentions and subsequent fertility behaviour. Population Trends 117: 9-19.

Billari, F.C. and H.P. Kohler 2004. Patterns of low and lowest-low fertility in Europe. Population Studies 58(2): 161-176.

Blossfeld, H. and C. Hakim 1997. Between equalization and marginalization: women working part-time in Europe and the United States of America. New York: Oxford University Press.

Blossfeld, H. and J. Huinink 1991. Human capital investments or norms of role transition? How women's schooling and career affect the process of family formation. The American Journal of Sociology 97(1): 143-168.

Bongaarts, J. and G. Feeney 1998. On the quantum and tempo of fertility. Population and Development Review 24(2): 271-279.

Bongaarts, J. 2001. Fertility and reproductive preferences in post-transitional societies. In Global fertility transition, ed. R.A. Bulatao and J.B. Casterline, 260-281. Supplement to Population and Development Review 27. New York, Population Council.

Brewster, K.L. and R.R. Rindfuss 2000. Fertility and women's employment in industrialized nations. Annual Review of Sociology 26: 271-296.

Callens, Marc. 1995. De 'Fertility and Family Survey' in Vlaanderen (NEGO V, 1991). De gegevensverzameling. CBGS Document 1995,4.

Connolly, S. and M. Gregory 2010. Dual tracks: part-time work in life-cycle employment for British women. Journal of Population Economics 23(3): 907-931. 
Desmet, B., I. Glorieux and J. Vandeweyer 2007. Wie zijn de loopbaanonderbrekers. Socio-demografische kenmerken, motivaties en arbeidshouding van loopbaanonderbrekers. TOR 2007(18).

Engelhardt, H. and A. Prskawetz 2004. On the changing correlation between fertility and female employment over space and time. European Journal of Population 20(1): $35-62$.

Frejka, T. and T. Sobotka 2008. Overview chapter 1: Fertility in Europe: Diverse, delayed and below replacement. Demographic Research 19(3): 15-46.

Friedman, D., M. Hechter and S. Kanazawa 1994. A theory of the value of children. Demography 31(3): 375-401.

Gadeyne, S., K. Neels and D. De Wachter (forthcoming). Monografie Nuptialiteit en Vruchtbaarheid op basis van de gegevens van de Sociaal-Economische Enquête 2001. Brussels: Federaal Wetenschapsbeleid.

Gauthier, A.H. 2007. The impact of family policies on fertility in industrialized countries: a review of the literature. Population Research and Policy Review 26: 323-346.

Ghysels, J. and W. Van Lancker 2009. Het Mattheüseffect onder de loep: over het ongelijke gebruik van kinderopvang in Vlaanderen. CSB Berichten. Antwerpen: Centrum voor Sociaal Beleid Herman Deleeck.

Goldstein, J., W. Lutz and M.R. Testa 2003. The emergence of sub-replacement family size ideals in Europe. Population Research and Policy Review 22: 479-496.

Gustafsson, S. 2001. Optimal age at motherhood. Theoretical and empirical considerations on postponement of maternity in Europe. Journal of Population Economics 14(2): 225-247.

Hakim, C. 2003. A new approach to explaining fertility patterns: preference theory. Population and Development Review 29(3): 349-374.

Heiland, F., A. Prskawetz and W.C. Sanderson 2005. Do the more-educated prefer smaller families? Vienna: Vienna Institute of Demography.

Hoem, J.M. 1986. The impact of education on modern family-union initiation. European Journal of Population 2: 113-133.

Juul, S., W. Karmaus, J. Olsen and the European Infertility and Subfecundity Study Group 1999. Regional differences in waiting time to pregnancy: pregnancy-based surveys from Denmark, France, Germany, Italy and Sweden. Human Reproducation 14(5): $1250-1254$.

Kravdal, Ø. 2002. The impact of individual and aggregate unemployment on fertility in Norway. Demographic Research 6(10): 263-294.

Kreyenfeld, M. 2002. Time-squeeze, partner effect of self-selection? An investigation into the positive effect of women's education on second birth risks in West Germany. Demographic Research 7(2): 15-48.

Kreyenfeld, M. 2006. Family formation in East and West Germany before and after unification. In Education and postponement of maternity, ed. S. Gustafsson and A. Kalwij, 225-236. Springer: European Association for Population Studies:

Kreyenfeld, M. 2010. Uncertainties in female employment careers and the postponement of parenthood in Germany. European Sociological Review 26(3): 351-366.

Lesthaeghe, R. 2002. Life course transitions and value adaptations: selection and adaptation. In Meaning and choice: value orientations and life course decisions, ed. R. Lesthaeghe, 1-44. The Hague \& Brussels: NIDI-CBGS Publications.

Lesthaeghe, R. and D. Meekers 1986. Value changes and the dimensions of familism in the European community. European Journal of Population 2: 225-268. 
Lesthaeghe, R. and K. Neels 2002. From the first to the second demographic transition: an interpretation of the spatial continuity of demographic innovation in France, Belgium and Switzerland. European Journal of Population 18(4): 325-360.

Lesthaeghe, R. and J. Surkyn 1988. Cultural dynamics and economic theories of fertility change. Population and Development Review 14(1): 1-45.

Lesthaeghe, R. and D. van de Kaa 1986. Twee demografische transities? In Bevolking: groei en krimp, ed. R. Lesthaeghe and D. van de Kaa. Deventer: Van Loghum Slaterus.

Lesthaeghe, R. and P. Willems 1999. Is low fertility a temporary phenomenon in the European Union? Population and Development Review 25(2): 211-228.

Liefbroer, A.C. 2009. Changes in family size intentions across young adulthood: a lifecourse perspective. European Journal of Population 25(4): 363-386.

Liefbroer, A.C. and M. Corijn 1999. Who, what, where, and when? Specifying the impact of educational attainment and labour force participation on family formation. European Journal of Population 15: 45-75.

Meggiolaro, S. and F. Ongaro 2008. Repartnering after marital dissolution: does context play a role? Demographic Research 19(57): 1913-1934.

Meron, M. and I. Widmer (transl. by D. Shapiro) 2002. Unemployment leads women to postpone the birth of their first child. Population-E 57(2): 301-330.

Mills, M., L. Mencarini, M.L. Tanturri and K. Begall 2008. Gender equity and fertility intentions in Italy and the Netherlands. Demographic Research 18(1): 1-26.

Neels, K. 2006. Reproductive strategies in Belgian fertility: 1930-1990. NIDI-CBGS Publications 38.

Neels, K. 2010. Temporal variation in unemployment rates and their association with tempo and quantum of fertility: some evidence for Belgium, France and the Netherlands. Paper presented at the Annual meeting of the Population Association of America, 15-17 April 2010.

Neels, K. 2011. Economic recession and first births in Europe: recession-induced postponement and subsequent recuperation of fertility in 14 European countries, 1970-2005. Paper presented at the Annual Meeting of the Population Association of America, 31 March-2 April 2011.

Neels, K. and D. De Wachter 2010. Postponement and recuperation of Belgian fertility: how are they related to rising female educational attainment? Vienna Yearbook of Population Research Vol. 8: 77-106.

Neyer, G. and G. Andersson 2008. Consequences of family policies on childbearing behavior: Effects or artifacts? Population and Development Review 34(4): 699-724.

OECD 2007. OECD Economic Surveys Belgium. OECD Publishing 2007/3.

OECD 2011. Doing better for families. OECD Publishing. http://dx.doi.org/10.1787/9789264098732-en

Philipov, D., Z. Spéder and F.C. Billari 2006. Soon, later, or ever? The impact of anomie and social capital on fertility intentions in Bulgaria (2002) and Hungary (2001). Population Studies 60(3): 289-308.

Philipov, D., O. Thévenon, J. Klobas, L. Bernardi and A.C. Liefbroer 2009. Reproductive decision-making in a macro-micro perspective (REPRO) State-of-the-art review. Vienna: Vienna Institute of Demography.

Régnier-Loilier, A. 2006. Influence of own sibship size on the number of children desired at various times of life: The Case of France. Population-E 61(3): 165-194. 
Schoen, R., N.M. Astone, Y.J. Kim and C.A. Nathanson 1999. Do fertility intentions affect fertility behaviour? Journal of Marriage and the Family 61(3): 790-799.

Singer, J. and J. Willett 2003. Applied longitudinal data analysis. Modeling change and event occurrence. Oxford: Oxford University Press.

Sobotka, T. 2008. Overview chapter 6: the diverse faces of the second demographic transition. Demographic Research 19(8): 171-224.

Sobotka, T. 2009. Sub-replacement fertility intentions in Austria. European Journal of Population 25(4): 387-412.

Sobotka, T. and W. Lutz. 2009. Misleading policy messages from the period TFR: should we stop using it? European Demographic Research Papers 4.

Sobotka, T., V. Skirbekk and D. Philipov 2011. Economic recession and fertility in the developed world. Population and Development Review 37(2): 267-306.

Spéder et al. 2010. Reproductive decision-making in a macro-micro perspective (REPRO). A summary of all findings in Work package 4. http://www.oeaw.ac.at/vid/repro/assets/docs/Summary_Realization.pdf.

Surkyn, J. and R. Lesthaeghe 2004. Value orientations and the second demographic transition (SDT) in Northern, Western and Southern Europe: an update. Demographic Research (special volume)3: 45-86.

Testa, M.R. 2007. Childbearing preferences and family issues in Europe: evidence from the Eurobarometer 2006 survey. Vienna Yearbook of Population Research Vol. 5: 357-379.

Thomson, E. and J.-C.A. Li 2002. Her, his and their children: childbearing intentions and births in stepfamilies. NSFH Working Paper 89.

Van Bavel, J. and D. De Wachter 2007. Uitstel van ouderschap in het Vlaamse Gewest, 2002-2006. Werkloosheid en werkonzekerheid vertragen de stap naar het moederschap bij de start van de 21 ste eeuw. In Vlaanderen Gepeild!, ed. J. Pickery, 359-397. Brussel: Studiedienst van de Vlaamse Regering.

van de Kaa, D.J. 2001. Postmodern fertility preferences: from changing value orientation to new behavior. Population and Development Review 27, Supplement: Global Fertility Transition: 290-331.

Van Peer, C. 2002. Kinderwens en realiteit: een analyse van FFS-gegevens met beschouwingen vanuit een macro-context. Bevolking en Gezin 31(1): 79-123.

Van Peer, C. 2008. Kinderwens in Vlaanderen. Een sociaaldemografische profielschets. Brussel: Studiedienst van de Vlaamse Regering.

Vikat, A. 2004. Women's labor force attachment and childbearing in Finland. Demographic Research (special volume)3: 177-212.

Vikat, A., E. Thomson and J.M. Hoem 1999. Stepfamily fertility in contemporary Sweden: the impact of childbearing before the current union. Population Studies 53(2): 211-225.

World Bank 2011. Education Statistics. http://data.worldbank.org/topic/education.

Wright, R.E and P.R.A. Hinde 1991. The dynamics of full-time and part-time female labour force participation in Great Britain. European Journal of Population 7: 201-230. 